\title{
Traction power consumption as a component of maximum speed choice on High Speed Lines
}

\author{
Andrzej Żurkowski ${ }^{1, *}$ \\ ${ }^{1}$ Railway Research Institute, ul. Chłopickiego 50, 04-275, Warsaw, Poland
}

\begin{abstract}
The paper includes briefly the most important methodological considerations for selecting the maximum speed for the newly designed HSL. They provide a context for discussion on energy aspects regarding traction energy costs. The research problem in question includes both the assessment of the absolute values associated with the consumption of traction energy and their reference to other costs and revenues associated with the operation of the High Speed Rail (HSR). The proposed approach is based on an analysis of the experience described in the international literature of the subject and simulation calculations for Polish conditions. Based on the approximate results and dependences in this field obtained by the railways with operational experience in relation to the typical HSR train sets, the records of dependencies which are most likely to be confirmed in Polish conditions are presented. Currently, $3 \mathrm{kV}$ DC is used on the railway network in Poland. This is therefore technically different from the one designed on HSL ( 25 $\mathrm{kV} \mathrm{AC}$ ), which the calculations are related to. Choosing the maximum speed for HSL must take into account the consumption of electricity because of its significant cost. However, the shortening of travel time by increasing the speed makes the HSR offer more attractive and thus allows for increased revenues. The final decision should therefore be a compromise based on detailed calculations, forecasts and simulations.
\end{abstract}

\section{Introduction}

The choice of the maximum speed of trains running on High Speed Lines (LDP) is one of the key elements determining the economic results of such an investment. The set of factors that should be taken into account is very extensive and includes technical, commercial, operational and economic parameters. Among them, the use of traction energy is also an important element. The article presents in a synthetic way the whole problem of choosing the speed on the High Speed Railway starting from the basic concepts, and then focusing on the conditions related to traction and its costs.

The considered batch problem includes both the assessment of absolute values related to the traction energy consumption, as well as their reference to other costs and revenues related to the operation of the HighSpeed Railway (KDP).

The proposed approach is based on the analysis of experiences described in the international subject literature and on simulation calculations for Polish conditions. The aim of such a comprehensive approach is to demonstrate that there are a number of rational premises for establishing the maximum speed both on Lines of High Speed and on upgraded lines, which is in contradiction with the often-presented approach. expert, based only on general ideas.

Choosing the maximum speed of trains on HSL (High Speed Lines) is one of the key factors in determining the economic performance of such an investment. The consumption of traction energy is an important determinant in the list of technical, commercial, operational and economic factors.

The paper presents the overall problem of speed selection, focusing on traction and cost aspects.

\section{Basic concepts related to railway speeds}

Speed classification in rail transport is based on the distinction of two basic types of speed:

- maximum $\left(v_{\max }\right)$ that are possible to achieve depending on the design and technical condition of railway lines, railway signaling and power systems and the type of rolling stock used,

- average speed $\left(v_{a}\right)$, which characterizes the operation process on railway.

For evident reasons $v_{a}<v_{\max }$. The exact list of speed types and their definitions are shown in Table 1 . The maximum speed of the train for the given operating conditions is equal to the lower of the two speeds: road and rolling stock:

$$
v_{t r}=\min \left(v_{r}, v_{r s}\right)
$$

The average speed of a given train is essentially due to the achievable maximum speed $v_{t r}$ and the method of organization of railway traffic, represented in the form of a timetable and described by means of the technical speed $v_{t}$.

From the passenger's traveler's point of view, the most important is the commercial speed $v_{c}$, which determines the total travel time on the $L$ route, which consists of $n$ sections. The relationship between the maximum and the average speed can be described by the so-called the maximum train speed utilization rate $w_{\max }$ form:

$$
w_{\max }=\sum_{i=1}^{n}\left(\frac{v_{c}^{i}}{v_{t r}^{i}} \cdot \frac{l_{i}}{L}\right)
$$

\footnotetext{
${ }^{*}$ Corresponding author: azurkowski@ikolej.pl
} 
$n$ - and the number of sections, which divided the entire route, $L$ - the length of the route $[\mathrm{km}]$,

$l_{i}-$ section $i$ length $[\mathrm{km}]$.

The $w_{\max }$ value is usually from $0.5-0.6$ on classic lines to $0.7-0.9$ on high speed lines [2]. It results from longer distances between stations on HS lines, line specialization and homogeneous train traffic, which translates into its incomparably greater liquidity. In practice, the value of $w_{\max }$ should be interpreted as a measure of the assessment of the use of the technical capabilities of railway lines in the rail operation process in relation to your rolling stock.

In accordance with the long-standing technical tradition, the maximum speed thresholds on the railways were defined as the total multiple of 20 , thus: 80,100 , $120,140,160$ or $200 \mathrm{~km} / \mathrm{h}$. Then, the threshold for High Speed Rail in Europe, previously indicated in Directive $2008 / 57$, is $250 \mathrm{~km} / \mathrm{h}$ (already without the above rule), and further on 280, 300, 320 and - as of today - 350 (380) $\mathrm{km} / \mathrm{h}$.

Table 1. Maximum and average speeds in rail transport.

\begin{tabular}{|c|c|c|c|}
\hline $\begin{array}{l}\text { Speed } \\
\text { type }\end{array}$ & $\begin{array}{l}\text { Name of } \\
\text { speed }\end{array}$ & Symbol & Definition \\
\hline \multirow{3}{*}{ 声 } & road & $v_{r}$ & $\begin{array}{l}\text { The speed achievable in a given } \\
\text { section of railway line. }\end{array}$ \\
\hline & rolling stock & $v_{r s}$ & $\begin{array}{l}\text { The speed that can be obtained } \\
\text { with a given type of rolling stock. }\end{array}$ \\
\hline & train ride & $v_{t r}$ & The speed of the train. \\
\hline \multirow{2}{*}{ 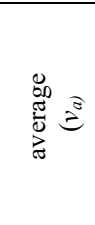 } & technical & $v_{t}$ & $\begin{array}{l}\text { The speed achieved by the train on } \\
\text { the whole route, with the deduction } \\
\text { of commercial stops at stations. }\end{array}$ \\
\hline & commercial & $v_{c}$ & $\begin{array}{l}\text { The speed achieved by the train } \\
\text { along the whole route, taking into } \\
\text { account commercial stops at } \\
\text { stations. }\end{array}$ \\
\hline
\end{tabular}

\section{Overview of the maximum speed key selection factors}

The set of criteria for selecting the maximum speed adequate to the conditions of a particular railway line can be systematized in three subsets, the classification proposed by M. Walrave [5, 6] is as follows:

- transport criteria, particularly important from the point of view of the carrier, determining in particular the share of rail in the transport market in a given corridor,

- technical and operational, i.e. related to the technical conditions of both the infrastructure and railway rolling stock understood comprehensively,

- social, including, among others, costs related to ecology (energy acquisition, noise), etc.

The criteria described in the three groups are the basis for the formulation of four functions, which together constitute the "economic balance of speed". All of them are non-linear and can be represented using the formulas listed in Table 2.

The set of parameters $\{A, \ldots, J\}$ for the presented functions requires a detailed analysis of a given system of connections by High-Speed Rail and taking into account local technical and economic conditions. Then, examining their course allows you to determine the optimum speed, which is shown schematically in fig. 1.

Table 2. Economic balance of speed.

\begin{tabular}{|c|c|c|c|}
\hline $\mathrm{N}^{\circ}$ & $\begin{array}{c}\text { Function's } \\
\text { name }\end{array}$ & Function's formula & $\begin{array}{c}\text { Type of } \\
\text { function }\end{array}$ \\
\hline 1 & $\begin{array}{c}\text { Journey } \\
\text { time }\end{array}$ & $\begin{array}{c}f_{c}(v)=A \cdot v^{B} \\
\mathrm{~A}>0 \text { and } \mathrm{B}<0\end{array}$ & power \\
\hline 2 & $\begin{array}{c}\text { Traffic \& } \\
\text { revenues }\end{array}$ & $\begin{array}{c}f_{p}(v)=C \cdot \ln (v)+D \\
\mathrm{C}>0 \text { and } \mathrm{D}>0\end{array}$ & logarithmic \\
\hline 3 & $\begin{array}{c}\text { Operating } \\
\text { costs }\end{array}$ & $\begin{array}{c}f_{k}(v)=E \cdot e^{F \cdot v} \\
\mathrm{E}>0 \text { and } \mathrm{D}>0\end{array}$ & exponential \\
\hline 4 & $\begin{array}{c}\text { Internal } \\
\text { benefits }\end{array}$ & $\begin{array}{c}f_{w}(v)=G \cdot v^{3}+H \cdot v^{2}+I \cdot v+J \\
\mathrm{G}, \mathrm{H}, \mathrm{I}>0\end{array}$ & polynomial \\
\hline
\end{tabular}

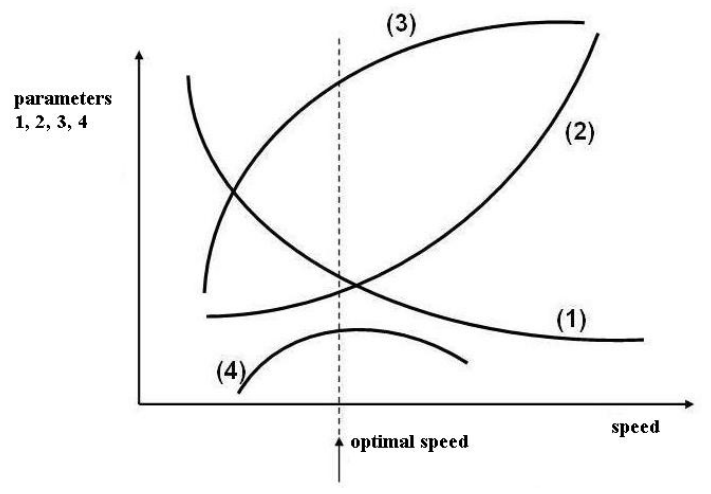

Fig. 1. Economically optimal speed [5].

The transport criteria relate to the issues of transport modeling [1]. The choice by means of a transport means from the so-called preferences, or features of transport services. The full set of preferences includes a dozen or so elements. The logit model [5, 7] describes their influence on the final decision of the traveler in relation to all possible transport means.

The High Speed Railways in relations with the length range from several hundred to about one thousand kilometers compete in principle with air transport. In this case, the market partition describes the so-called pricetime model [7]. It is based both on the calculation of travel time and its price, as well as on the individual assessment of the time of the traveler.

The choice of the maximum speed of trains is therefore of major commercial importance, as it decides about participation in the total passenger transport market. Referring to the passenger transport market in Europe, it can be concluded that the share of rail in modal split, amounting to $6.7 \%$ for several years, remains steady at this level thanks to the development of the KDP system, which already carries $25.7 \%$ of all rail passengers $\mathrm{s}^{\mathrm{a}}$.

The choice of the maximum speed of trains on the considered LDP can therefore start from determining the set of permissible solutions and at the same time assume that the maximum speed limit currently is $574,8 \mathrm{~km} / \mathrm{h}$. From a theoretical point of view, speed optimization can

${ }^{a}$ EU Energy \& Transport. Statistical pocketbook 2017, European Commission 2018. 
lead to a solution of any value $v_{\max }$ from the range of, for example, $200 \ldots 570 \mathrm{~km} / \mathrm{h}$. The maximum speed limits used on the rail limit the actual selection to values divided by the number 10 .

The first step in speed selection should therefore be to set several thresholds to be used, no. $250,280,300$ or $320 \mathrm{~km} / \mathrm{h}$. Turning then to the economic plane, it seems reasonable to analyze for each of these speeds the costs and benefits (revenues) associated with the four basic groups of conditions: technical, economic, operational and commercial. Their combination and critical analysis should make it easier to choose the maximum velocity of the most-preferred High Speed Line under certain conditions.

\section{Traction power consumption as a factor of maximum speed choice}

The amount of energy used for traction purposes depends on many factors related to the investment process of designing and building the High Speed Line, the type of used rolling stock, as well as operational methods.

The impact of the construction of High Speed Line on the amount of energy consumed is related to:

- its geometrical profile, both vertical (elevation) and horizontal (number and radius of arcs,

- engineering structures (tunnels, viaducts) implying possible speed limits or changes in train resistance,

- the number and arrangement of tracks on intermediate stations or outposts and the permissible speeds when crossing them,

- the type of traction power system used (DC - direct current, AC - alternating current, frequency).

The impact of rolling stock construction on energy consumption includes:

- aerodynamic resistance related to the shape of the train bodies,

- the power of traction motors and the manner of their arrangement (concentrated - traction components at the ends of the train or traction deployed on the length of the train - EMU),

- type of the technical construction - mechanical energy consumption.

Both the technology of designing and building the High Speed Line as well as the composition of the sets results from the progress of relevant engineering disciplines. The amount of energy consumption depends on the generation (year of production) of vehicles and the modernity of the innovative solutions used.

The exploitation process has a very large impact on energy consumption. The type of railway traffic control system, cabin signaling, etc. is of particular importance in this regard.

At the same time, the key skills and experience of the driver are key. With high saturation of the lines and the resulting short time of train succession, the energy consumption increases in the case of frequent deceleration and acceleration.

The possibilities of significant progress in this area are related to the autonomy of running trains (ATO Automatic Train Operations system). Such solutions have been used for many years on subway lines and on aero-rails.

Practical implementation of them on the railway is possible primarily on lines completely separated from road and pedestrian traffic and used for transports realized with a homogeneous type of vehicles. Such conditions exist, for example, on agglomeration railway lines in city centers and on Lines of High Speed.

The existing systematic of train traffic automation (Grade of Automation) covers four levels. The lowest level - GoA 1 refers to the case of a train driven by the driver with the cab signaling, while the highest one Goa 4 means a completely unmanned train.

The advantages of such a system consist in the possibility of full application of train traffic based on the so-called movable block sections. In this way, the fluidity of train traffic is optimized, which at the same time translates into optimal, minimal traction energy consumption on the whole line.

Prospects for the use of such solutions on the leading European railways concern the next few years. It is worth pointing out that the automatic acceleration and braking of trains (GoA 2, 3 and 4) already allow for the optimization of energy consumption for individual trains to a large extent.

The costs of energy used for traction purposes include:

- charges for energy collected (at the substation's entrance),

- refund for recovered energy (recuperation),

- energy supplier fees for distribution management,

- brokerage costs charged, for example, by the infrastructure manager.

It should be noted that the traction energy consumed also includes transmission losses over the traction network (in the substation-pantograph section), and in the case of recuperation - the possibility of energy recovery recovered at the unit rate of energy supplied. At the same time, distribution costs are usually calculated in proportion to the costs of delivered energy.

Making a comparative assessment of traction energy costs from the point of view of the carrier requires its reference to one inventory place in the train (to the seat$\mathrm{km})$ or for one train-km [3].

On Polish railways the highest train speeds are obtained on the Central Trunk Line (CMK). For more than $60 \%$ of the length of this line, the ED250 Pendolino trains run at a speed of $200 \mathrm{~km} / \mathrm{h}$, which in the light of the Railway Interoperability Directive (2016/797, Annex I) means the High Speed Rail.

Using the mathematical formulas [3] elaborated for the HSR [8], the costs of traction energy consumption were referred to the CMK line. 


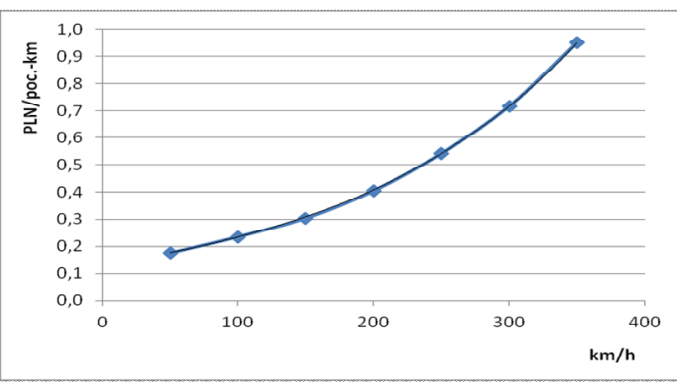

Fig. 2. Traction energy costs in Polish conditions [8].

By denoting $C_{e}$ as energy consumption, this his relationship can be described by the formula $\left(\mathrm{R}^{2}=\right.$ 0,9998):

$$
C_{e}(v)=0,1336 \cdot e^{0,0056 \cdot v}
$$

The above pattern is of course indicative, but confirms the exponential increase in energy costs as a function of the speed of train.

I would like to formulate a comment on this relationship from the position of an expert who has been dealing with the issue of rail passenger transport for nearly forty years: both from the theoretical and practical side - managing the railway operator. The cost of energy is an important item in the budget of the operator, but if such an expense leads to shortening the time of train travel and acquiring additional passengers, then it should not be a limitation in this respect.

This applies both to the situation of direct connections between cities, as well as between interchanges. The speed of trains should be shaped also in relation to the possibility of connecting trains and changing passengers.

Probably greater savings in energy consumption can be obtained through the use of ATO systems, thanks to the optimal acceleration and braking of the train as well as the resulting fluidity of railway traffic on lines and at railway junctions.

\section{Conclusions}

With the problem of choosing the maximum speed of trains on KDP lines, a set of possible solutions is finite and countable, and the space of acceptable solutions is determined by technical conditions and railway operation rules.

The chosen "optimal" speed belongs to the set of practical "railway" speeds. Energy for traction purposes is an important element of calculation and increases exponentially as the speed of the train increases,
In order to determine the optimal speed, the simplest method is to perform an economic calculation and to examine the technical, organizational and commercial consequences successively for all possible optimal speeds.

Currently, the maximum speeds on High Speed Lines are shaped based on the assessment of local conditions and technical possibilities.

Until now, a $3 \mathrm{kV}$ DC voltage is used on the railway network in Poland (including the CMK line). Therefore, it is a technically different situation than the one for the $25 \mathrm{kV}$ high-speed AC line being designed).

The choice of the maximum speed should take into account the consumption of electricity due to its significant cost. Shortening the travel time by increasing the speed increases the attractiveness of HSR connections, and thus allows you to increase revenues. The final decision should therefore be a compromise based on detailed calculations, forecasts and simulations.

\section{References}

1. M. Lebœuf, Grande vitesse Ferroviaire. Cherche Midi, (Paris, 2013)

2. A. Massel, Wykorzystanie prędkości maksymalnej pociagów [The use of the maximum speed of trains]. Problemy Kolejnictwa, 4 (2017)

3. G. Rus (ed.), Economic Analysis of High Speed Rail in Europe, (BBVA, Bilbao, 2009)

4. M. Siergiejczyk (ed.), Koleje Dużych Prędkości w Polsce [High Speed Rail in Poland], (Instytut Kolejnictwa, Warszawa, 2015)

5. M. Walrave, Analyse économique et financière des projets Grande Vitesse, Formation Systèmes Grande Vitesse, (UIC, Paris, 2007)

6. M. Walrave, 9 main issues about the optimal Speed, UIC $6^{\text {th }}$ World Congress on High Speed Rail, (Amsterdam, 2008)

7. A. Żurkowski, Price-time model Applied in Assessment of Rail Market Share in Passenger Traffic in Transport Corridor. The Archives of Transport, No 3-4, Vol. XXI (2009)

8. A. Żurkowski, Przestanki wyboru prędkości maksymalnej pociagów na liniach szybkiego ruchu [Premises for choosing the maximum speed of trains on fast lines], Logistyka, 4 (2012)

9. A. Żurkowski (ed.), High-Speed Rail in Poland, (Balkema, 2018) 